OPEN ACCESS

Edited by:

Mariusz Lamentowicz,

Adam Mickiewicz University, Poland

Reviewed by:

Daniele Colombaroli,

Royal Holloway, University of London, United Kingdom

Terri Lacourse,

University of Victoria, Canada

${ }^{*}$ Correspondence:

H. John B. Birks

John.Birks@uib.no

Specialty section:

This article was submitted to

Paleoecology,

a section of the journa

Frontiers in Ecology and Evolution

Received: 20 March 2020

Accepted: 12 May 2020

Published: 29 May 2020

Citation:

Birks HJB (2020) Reflections on the Use of Ecological Attributes and Traits in Quaternary Botany.

Front. Ecol. Evol. 8:166.

doi: 10.3389/fevo.2020.00166

\section{Reflections on the Use of Ecological Attributes and Traits in Quaternary Botany}

\author{
H. John B. Birks ${ }^{1,2 *}$ \\ ${ }^{1}$ Department of Biological Sciences and Bjerknes Centre for Climate Research, University of Bergen, Bergen, Norway, \\ ${ }^{2}$ Environmental Change Research Centre, University College London, London, United Kingdom
}

There has been an upsurge of interest and research activity in trait-based approaches in ecology, biogeography, and macroecology. I discuss if this upsurge has impacted Quaternary botany (the study of plant remains preserved in sediments). I show that ecological attributes (including traits) have played and continue to play an integral part in the interpretation of Quaternary botanical data in terms of reconstructing past environments and interpreting long-term changes in plant assemblages. This use started over 120 years ago and continues to the present. It is unclear if a "new" Quaternary botany based on traits will develop because of the taxonomic limitations of much Quaternary botanical data.

Keywords: climate, ecological indicator values, environmental reconstruction, functional diversity, plant functional types, plant macrofossils, pollen analysis

\section{INTRODUCTION}

In modern plant ecology there has been a great upsurge of interest and research effort in traitbased ecology in the last 20 years (e.g., Shipley, 2010; Garnier et al., 2016) since the pioneering efforts of ecologists in the early 20th century (e.g., Raunkiaer, 1907; Blackman, 1920; Raunkiaer, 1934; Iversen, 1936) and late 20th century (e.g., Grime, 1979; Bloom et al., 1985; Jurado et al., 1991; Leishman and Westoby, 1992; Grime, 2001; Westoby et al., 2002). The trait-based approach extends back at least to 300 BCE (Theophrastus, 1916; Weiher et al., 1999). This recent upsurge in trait-based ecology proposes "Rebuilding community ecology from functional traits" (McGill et al., 2006), "... using plant functional traits to understand ecological processes" (Funk et al., 2017), "predicting communities from functional traits" (Cadotte et al., 2015), and "using functional traits to predict ecosystem change" (Suding and Goldstein, 2008). Using functional traits to generalize complex community assembly and dynamics and to predict effects of environmental change on ecosystems is referred to as a "Holy Grail" in ecology (e.g., Lavorel and Garnier, 2002; Suding and Goldstein, 2008; Funk et al., 2017). Recent publications have spectacular titles such as "Predictive traits to the rescue" (Guisan, 2014), "Trait-based assessment of climatechange impacts on interacting species" (Schleuning et al., 2020), "Functional traits explain the Hutchinsonian niches of plant species" (Treurnicht et al., 2020), and "Elevation gradient of successful plant traits for colonizing alpine summits under climate change" (Matteodo et al., 2013). Trait-based approaches have also been proposed to create a "functional biogeography" that "bridges species-based biogeography and earth science to provide ideas and tools to explain gradients in multifaceted diversity (including species, functional, and phylogenetic diversities), 
predict ecosystem functioning and services worldwide, and infuse regional and global conservation programs with a functional basis" (Violle et al., 2014, p. 13690).

Given the considerable interest and activities in traitbased approaches in contemporary plant-community ecology, ecosystem ecology (Díaz and Cabido, 2001), biogeography (Violle et al., 2014), and macroecology (He et al., 2019), are these current interests and activities impacting Quaternary botany? In this article, I discuss the use of ecological attributes and traits in Quaternary botany over the last 120 years and show that such use has been and remains an integral part of the subject. I first present some essential definitions. I then discuss the use of ecological attributes and then review the use of ecological traits in Quaternary botany. I conclude by discussing if a traitbased approach can contribute further to Quaternary botany and outline what the major limitations of developing this approach further are in Quaternary botany.

\section{DEFINITIONS}

Quaternary (last 2.6 million years) botany involves the study of plant megafossils (e.g., tree stumps, logs, and wood remains), plant macrofossils (e.g., seeds, fruits, leaves, and bryophyte remains), and plant microfossils (e.g., pollen, spores, phytoliths, charcoal, and non-pollen palynomorphs) preserved in peat and in lake and ocean sediments. Although megafossils and macrofossils have been studied since the late 18th century, Quaternary botany today is dominated by pollen analysis (Birks, 2019).

Ecological attributes (=ecological characteristics) are features of a taxon such as its range size, life history, geographical distribution, climatic tolerances, habitat types, environmental indicator values, edaphic preferences, and so on, that describe the overall ecology of the taxon (Hill et al., 2004; Hill et al., 2007).

Ecological traits have been defined in several ways (e.g., Semenova and Van Der Maarel, 2000; Violle et al., 2007; Shipley, 2010; Garnier et al., 2016; Körner, 2018). A definition that is widely adopted is that a trait is "a well-defined, measurable property of organisms, usually measured at the individual level and used comparatively across species. A functional trait is one that strongly influences organismal performance" (McGill et al., 2006, p. 178). There are other types of traits used in ecology such as vital attributes and ecophysiological, stress tolerance, life-history, demography, biology, response, performance, effect, neutral, and a posteriori traits (Violle et al., 2007; Garnier et al., 2016; Körner, 2018). Traits are always attributes, but many attributes such as geographical distribution are not traits because they may depend on historical accidents. A trait is thus an attribute that can, in theory, be observed in an individual plant and is intrinsic to its genome, whereas an attribute is a property of a taxon considered as a whole (Hill et al., 2019, pers. comm.). Deciding whether a trait is 'functional' in the sense of being "important for performance" is not always clear (see Weiher et al., 1999; Diaz et al., 2004; Bernhardt-Römermann et al., 2008; Shipley et al., 2016). Körner (2018) noted that "it appears that often certain traits are thought to be important because they have been measured because tools have been available. There are many traits that are potentially of great value; however, they have not been accounted for because their study is very laborious, or they have not yet been thought of." Here I use the general term "trait" except when the type of trait being discussed is clear.

This review only considers Quaternary botany. Testate amoebae are not considered even though they are often studied in conjunction with botanical studies on peat sequences (e.g., Fournier et al., 2015; Lamentowicz et al., 2015; Marcisz et al., 2016; Marcisz et al., 2020).

\section{ECOLOGICAL ATTRIBUTES}

The first use of ecological attributes, in this case a species distribution and its inferred climatic limits and tolerances, to reconstruct past climate change is probably the classic work by Andersson (1902, 1903, 1909). He mapped the occurrence of fossil Corylus avellana (hazel) nuts in Swedish and Norwegian peats. He showed that the present-day northern limit of hazel coincided closely with the mean July temperature isotherm of $12^{\circ} \mathrm{C}$ but fossil nuts occurred as far north as today's July isotherm of $9.5^{\circ} \mathrm{C}$ (see Birks, 2008). Andersson proposed that mean July temperature in the early- and mid-Holocene was 2$2.5^{\circ} \mathrm{C}$ warmer than today. Following this, Samuelsson (1916) analyzed hazel's present-day northern limit in greater detail. He showed that summer temperature was not uniform along today's limit and that a lower summer temperature was compensated for by a longer growing season (Birks, 2008). He modeled the climatic demands of hazel in terms of both summer temperature and growing-season duration and proposed that both summer and winter temperature, and hence growing-season length, had changed during the Holocene (Birks, 2008). He emphasized that the occurrence of fossil hazel nuts does not give a direct single paleoclimatic estimate but a range of possible values, each corresponding to a given growing-season duration (see also Faegri, 1950; Birks, 2008). These pioneering studies led to the unique study by Iversen (1944) on the climatic tolerances of Viscum album, Hedera helix, and Ilex aquifolium in Denmark.

On the basis of detailed field observations over several years, Iversen (1944) delimited the "thermal limits" or "bioclimatic envelopes" within which these three shrubs flowered and produced seed [the Grinnellian (Grinnell, 1917) and regeneration niches (Grubb, 1977)] within Denmark. Iversen (1944) showed that Ilex is intolerant of cold winters but tolerant of cold summers. Hedera is intolerant of winters with mean temperatures less than $-1.5^{\circ} \mathrm{C}$ but requires warmer summers than Ilex. Viscum is tolerant of cold winters but requires warmer summers than either Ilex or Hedera. These taxa are ideal "indicator species" because their pollen is readily identifiable to species level and is not blown great distances so "false positives" are unlikely, and their fruits are rapidly dispersed by birds (Iversen, 1944). Their distributions, at least at the scale of Denmark, are likely to be in equilibrium with climate (Birks et al., 2010). The validity of this critical assumption is elegantly demonstrated by Walther et al. (2005) who showed that the northern limit of Ilex has shifted northwards in Scandinavia in the last 50 years, presumably in response to milder winters in recent decades 
(Birks, 2008). From fossil pollen occurrences, Iversen (1944) applied his modern climate envelopes (attributes) to infer that mid-Holocene summers were $2-3^{\circ} \mathrm{C}$ warmer and winters were $1-2^{\circ} \mathrm{C}$ warmer than today in Denmark.

The general "bioclimatic envelope" approach of Andersson, Samuelsson, and Iversen has been extended to consider the climatic limits based on the current distributions of several taxa simultaneously to identify areas of climatic overlap for pollen, plant macrofossils, and other organisms, the so-called Mutual Climate Range (MCR) approach (Atkinson et al., 1986; Birks et al., 2010). Attempts have been made to narrow the climate range inferred by MCR (e.g., Marra et al., 2004; Marra et al., 2006) with varying success (see Birks et al., 2010 for details).

Kühl et al. (2002) and Kühl (2003) combined the various approaches outlined above to develop a rigorous means of inferring past climate based on presence/absence data (e.g., plant macrofossils) involving probability density functions (pdfs). It combines modern distributions for individual taxa with gridded modern climate data and summarizes the modern climate limits of the taxa as conditional pdfs (climate| taxon present) rather than as ranges or thresholds (Birks et al., 2010). A normal distribution is used to estimate the pdf. By assuming statistical independence, a joint pdf is calculated for a fossil assemblage as a product of the pdfs of the individual taxa in the assemblage. Each taxon is weighted by the dispersion of the modern climate range, so "narrow" indicators carry "high" weight. The pdf product is the most likely past climate and its mean and confidence intervals are inferred to be the most probable climate and its uncertainty (Birks et al., 2010). The reconstructed climate is based on the complete distribution and climate data of all taxa considered and because it is a multiplicative technique, no single taxon is decisive (Kühl and Litt, 2003). The pdf approach has been used in infer Holocene and last interglacial climate from pollen assemblages (expressed as presence/absence; e.g., Kühl, 2003; Kühl and Litt, 2003; Litt et al., 2009). The approach has been extended to become a Bayesian indicator taxon model (Neumann et al., 2006). This development combines the conditional pdfs with the prior probability density of climate to estimate Bayesian posterior pdfs. Two-dimensional normal distributions are used as parametric functions to describe the conditional pdfs of mean July and January temperature, thereby allowing the influence of these two climatic variables to be considered together and hence for both to be inferred simultaneously (Kühl and Gobet, 2010). Recent developments in the pdf approach (Chevalier et al., 2014; Chevalier and Chase, 2015; Chevalier, 2019) have extended it to use pollen percentages and to consider the dimensionality and modality of the fitted pdfs.

This correlative approach of comparing modern distributions with contemporary climatic variables has proliferated in biogeography and global-change ecology in the last 20 years (e.g., Franklin, 2010). It is variously called bioclimatic-envelope, species-distribution, or species-niche modeling, and involves a range of spatial regression techniques. The assumptions common to all these models to infer past or future climate or taxon distributions are (i) that contemporary distributions are controlled by climate, (ii) that such distributions are in equilibrium with climate today, (iii) that the distributional and climatic data are reliable, and (iv) that the observed realized distribution area is close to the potential and fundamental distribution areas (e.g., Pearson and Dawson, 2003; Dormann, 2007; Beale et al., 2008; Birks et al., 2010; Svenning and Sandel, 2013; Birks, 2019). The greatest uncertainties are whether climate limits the observed distribution and the whether the distribution is in equilibrium with climate. These assumptions are critical in all bioclimatic-envelope models used to infer past or future climate or taxon distributions from contemporary climatic and distributional data (Svenning et al., 2011).

Prior to 1916, Quaternary botany only considered megafossils (logs, tree stumps, etc.) and macrofossils (leaves, seeds, and fruits, etc.). It underwent a major change in 1916 as a result of von Post's seminal lecture in Kristiania (Oslo) in July (Von Post, 1916, 1918) in which he presented the principles and methodology of pollen analysis, discussed problems of interpretation, and demonstrated its potential as a tool for studying temporal and spatial changes in pollen assemblages and hence in vegetation. At first, pollen analysis was confined to trees and used to reconstruct forest history and climate change and to provide a relative dating technique. The taxonomic resolution of pollenstratigraphical data greatly improved in the 1930s and 1940s through the work of, inter alia, Franz Firbas, Gunnar Erdtman, Jørgen Troels-Smith, and Johannes Iversen (Birks and Berglund, 2018). This culminated in the publication of the Text-book of Modern Pollen Analysis (Faegri and Iversen, 1950). As a result, pollen analysis began to shift from being primarily a tool in Quaternary geology to a tool in Quaternary botany and paleoecology. Aspects of the ecology of taxa found as fossils (e.g., light, moisture, and soil preferences, geographical distribution, climatic tolerances-“ecological attributes” sensu Hill et al. (2004)] were increasingly used in the interpretation of pollen-stratigraphical data. Examples of this approach include Iversen's demonstration of the influence of prehistoric people on vegetation and the interpretation of the ecological changes resulting from forest clearance (Iversen, 1941, 1949, 1973), and of the unique nature of the flora, vegetation, and environment of the late-glacial interval in Denmark (Iversen, 1954, 1973).

At about the same time, ecologists began to use modern plant assemblages as a basis for assessing modern environmental conditions, co-called bio-indication, by means of ecological indicator values (EIVs; e.g., Ellenberg, 1948). Ordinal EIVs ("optima") have been estimated for the central European flora on the basis of field, laboratory, and phytosociological studies for light, moisture, soil reaction, nitrogen, salt tolerance, temperature, and continentality (Ellenberg et al., 1992). Given a modern plant assemblage, the environmental values for its site is inferred to be the average of the indicator value (if presence/absence data only are available), or the abundanceweighted average (Holtland et al., 2010) of the indicator values if quantitative or semi-quantitative data are available. EIVs may vary between large geographical areas (e.g., Lawesson et al., 2003; Godefroid and Dana, 2007), and Hill et al. (2000) developed an iterative numerical procedure for extending Ellenberg's EIVs into new areas (e.g., Hill et al., 2004; Hill et al., 2007). Diekmann (2003) and Kollmann and Fischer (2003) provide a thorough review of EIVs as a tool in applied ecology. Excellent examples 
of their use in modern ecology include (Hawkes et al., 1997; Hill and Carey, 1997; Dzwonko, 2001; Cornwell and Grubb, 2003; Bennie et al., 2006; Holtland et al., 2010; Hellegers et al., 2020). The underlying mathematical basis for the use of EIVs is outlined by Ter Braak and Barendregt (1986); Ter Braak and Gremmen (1987), and Holtland et al. (2010).

EIVs have been partially criticized for being subjective and semi-quantitative, not being based on field measurements, and being based, in part, on central European phytosociological classes. However, the current general consensus about their robustness was well summarized by Körner (2018; an ecophysiologist) as follows. "While such semi-quantitative estimates may not allow us to identify accurately physiologically based preferences within an individual plant species (for instance between an indicator value of 3 or 4 ), it is surprising how well mean indicator values reflect site characteristics across several species in a given community. As such, indicator values may reflect habitat conditions more accurately than physico-chemical analyses of soil because they represent a long-term response of species to habitat conditions. ... Indicator values are a reliable tool for making predictions about plant community changes in relation to changes in environmental conditions. Communitylevel indicator values represent a trait syndrome that can be validated." Körner (2018) considered EIVs to be an a posteriori trait concept, namely traits that reflect "observed responses to the environment, rather than responses predicted by theory." Van Der Maarel (1993) viewed EIVs from a phytosociological and field ecological viewpoint and concluded that "ecological indicator values have a valuable element of synthesis and integration which incidental measurements may miss."

Körner (2018) proposed that EIVs are similar to the plant life-strategies proposed by Grime $(1979,2001)$ in both being $a$ posteriori traits. Interestingly, Thompson et al. (1993) showed close relationships between EIVs and quantitative measurements from both the field and from laboratory screening experiments (e.g., rooting depth, foliar Ca values, foliar $\mathrm{N}$ concentrations, and iron tolerance). Thompson et al. (1993) noted that "We have attempted to marry the Ellenberg tradition with the screening approach of UCPE [Unit of Comparative Plant Ecology], Paul Keddy, Mark Westoby, and others. [Our results] suggest that the two are complementary and that each has much to gain from an interaction with the other." This view, presented over 25 years ago, was rejuvenated by Bartelheimer and Poschlod (2016) in their review of functional characterizations of Ellenberg values in relation to ecophysiological variables such as maximum frost resistance, time of leaf unfolding, maximum relative growth rate, embryo + endosperm weight, and time to $50 \%$ germination. They concluded (p. 506) "Functional characterizations of the different EIVs can thus be deduced which help to understand the mechanisms and processes driving the ecological niche of a plant."

Despite the many demonstrations of the robustness of EIVs in environmental inferences (e.g., Van Der Maarel, 1993), the increasing discoveries of the links between EIVs and functional characteristics of species (e.g., Thompson et al., 1993), and the increasing use of EIVs in ecology from 20 studies in 1985-1989 to 277 studies in 2010-2014 (Bartelheimer and Poschlod, 2016),
EIVs are surprisingly rarely used in Quaternary botany despite their numerical simplicity and robustness. They have been used primarily with macrofossil assemblages where species-level identifications are often possible (Birks, 2001, 2013, 2014). EIVs have been used to infer local-scale conditions of light, soil reaction (=calcium and hence pH: Schaffers and Sýkora, 2000), soil nitrogen (=soil fertility or aboveground productivity: Hill and Carey, 1997), and soil moisture from late-glacial macrofossil assemblages (e.g., Mortensen et al., 2011; Felde and Birks, 2019), from assemblages associated with archeological sequences (e.g., Wasylikowa, 1978; Wasylikowa et al., 1985; Wasylikowa, 1989; Cappers, 1993/1994), and from fossil bryophyte assemblages (e.g., Odgaard, 1981; Jonsgard and Birks, 1995; Lamentowicz et al., 2015; Zechmeister et al., 2019).

The use of EIVs is more problematic with pollenstratigraphical data as most pollen types can currently only be identified to genus or family level. Naturally there are very few uses of EIVs with pollen assemblages (e.g., Birks, 1990; Kuneš et al., 2011; Reitalu et al., 2015; Enevold et al., 2019). Genus or family level pollen identifications necessitate deriving a mean or median EIV for taxa growing in the relevant study area today (e.g., Birks, 1990; Kuneš et al., 2011; Reitalu et al., 2015). Enevold et al. (2019) derived EIVs for light, moisture, soil fertility, and $\mathrm{pH}$ for a terrestrial pollen type as the mean of the EIV for the regionally dominant or common species today, if five or more species contribute to that pollen type or, if four or fewer species are included in that type, a mean EIV for all those species is used. The same approach was used to derive EIVs for wetland macrofossil taxa if a taxon represented more than one species (Enevold et al., 2019). Given mean or median EIVs for the pollen types present, an assemblage-weighted mean (=community-weighted mean: Diekmann, 2003) can be used to infer past environmental conditions.

EIVs have considerable potential value in inferring past environments from Quaternary botanical data; one factor that limits their use is the importance of having taxonomically detailed assemblage data. There is a current marked decline in macrofossil studies globally and this may render EIV approaches very rare or impossible in the future.

\section{ECOLOGICAL TRAITS}

Turning to the use in Quaternary botany of what modern plant ecologists may term traits, perhaps the first use is the simple functional division of pollen taxa into arboreal and nonarboreal pollen (Firbas and Preuss, 1934; Reitalu et al., 2015). The division has been almost universally used by palynologists worldwide for over 90 years. An extension of this division has been the use of plant functional types (PFTs) to assign pollen assemblages into biomes as a means of reconstructing major broadscale distributions of inferred vegetation (e.g., continents) and of using past vegetation data in Earth system models (e.g., Prentice et al., 1996; Fyfe et al., 2010; Collins et al., 2012; Davis et al., 2015; Zanon et al., 2018). They have also been used to summarize modern and fossil pollen assemblages in the quantitative reconstruction of past climate (e.g., Davis et al., 2003; 
Brewer et al., 2008; Mauri et al., 2015) and past forest cover (e.g., Zanon et al., 2018). Gachet et al. (2003) applied a probabilistic approach to characterize modern pollen taxa using one or more modes of several attributes or traits (e.g., climatic preferences, stature, phenology, and life-form). Conditional probabilities were defined to represent the probability that a given attribute mode occurs in a given pollen sample when the pollen assemblage is known. They compared their approach using modern pollen samples with existing biome classifications and remote-sensing data. They then used their approach to reconstruct biomes for 6000 years ago from European fossil data. This approach does not appear to have been used since the original study.

Using 302 modern pollen assemblages from the Mediterranean region, Barboni et al. (2004) identified "plausible trends" in the frequency of traits of 12 plant morphological and phenological characteristics. Combinations of traits appeared to be more climatically diagnostic than individual traits. The major patterns in trait frequencies were correlated with available moisture, winter temperature, or a combination of both. Traits such as leaf size, texture, thickness, pubescence, thorniness, aphylly, and aromatic leaves also varied, not surprisingly, with life-form, leaf-type, and phenology (Barboni et al., 2004).

Iversen (1960) used data from the pioneering work of Vaupell (1863) on the different shade tolerances, longevities, reproduction behavior, and edaphic preferences of the major forest trees in Denmark to present a null hypothesis for the early- and mid-Holocene forest development solely in terms of endogenous biotic interactions (Birks, 1986, 2019). Vaupell (1863) showed the importance of light in woodland successional dynamics in which light-demanding taxa are replaced over time by shade-tolerant trees, provided that conditions for growth are favorable for the latter (see also Jensen, 1910, 1949; Iversen, 1941). Following Iversen (1960), Birks (1986) compiled 20 general traits of trees characteristic of the protocratic, mesocratic, and oligocratic + telocratic phases of an interglacial cycle in northwest Europe (Iversen, 1958; Birks and Birks, 2004; Birks, 2019). These traits include crown geometry, seedling light tolerance and mortality, growth rate, life-history features, longevity, and age and frequency of seed set (Birks, 1986).

Attributes such as longevity, seed size, vegetative reproduction, habitat preference, and geographical distribution, termed biogeographical traits by Bhagwat and Willis (2008), were used as presence/absence variables to assess differences in the attributes of taxa that persisted in the last glacial maximum only in refugia in southern Europe ("macrorefugia" Birks, 2019) or taxa that also grew in refugia in both southern and northern Europe ("microrefugia" or "cryptic refugia" Bhagwat and Willis, 2008; Birks and Willis, 2008; Birks, 2019). Taxa confined to southern refugia only are mainly large-seeded angiosperms, whereas taxa that also grew in more northerly microrefugia are mostly wind-dispersed and often, but not always, show vegetative reproduction (Bhagwat and Willis, 2008).

Lacourse (2009) used life-history and stress-tolerance traits such as minimum seed-bearing age, waterlogging, shade, and drought tolerances, size longevity, seed mass, and relative growth rate (RGR) for 11 taxa, ten of whose pollen can be assigned to species level in the context of coastal British Columbia. The one exception not assignable to species level was Populus pollen which could be derived from P. trichocarpa or P. balsamifera. The traits used for Populus were the means for the two species. Lacourse compiled independent paleoenvironmental data for her pollen sequence such as summer insolation, mean annual precipitation, coastal sea-surface temperatures, and biomass. Both RLQ (Dolédec et al., 1996) and fourth-corner (Legendre et al., 1997) analyses were used to link the traits to past environment over the last 15,000 years through the fossil pollen record from Misty Lake, British Columbia and hence to help interpret the ecological patterns and their underlying processes at the site. RLQ analysis showed that relative growth rate and temperature were most strongly correlated with the major longterm variation in pollen stratigraphy. Both numerical analyses showed statistically significant correlations between many of the other traits and insolation and temperature changes. Following deglaciation climate change appears to have favored taxa with high RGR, short life-span, and low shade tolerance (e.g., Alnus sinuata, Pinus contorta), whereas in the last 8000 years, climatic stability favored taxa such as Tsuga heterophylla with its low RGR, long life-span, and high shade tolerance. Fourth-corner analysis modified for abundance data (Dray and Legendre, 2008) showed correlations between all paleoenvironmental variables and most traits, but the strongest was between temperature and plant height, reflecting the dominant competitive abundance of tree height. Lacourse (2009) concluded that exogenous climate was the ultimate control on early-Holocene forest composition and taxon abundance but in the last 8000 years long-term forest vegetation composition was constrained through endogenous interspecific differences in traits, a conclusion similar to Iversen (1960) in his analysis of forest development in Denmark. An important general conclusion from Lacourse's (2009) pioneering quantitative study is that a suite of traits and trait differences, as opposed to a single trait, were important in mediating changes in the long-term forest composition in the Pacific North West that were primarly driven by climate, just as Iversen (1960) showed in his qualitative analysis that several ecological attributes or traits were important in understanding the Holocene forest development in Denmark.

There has been a small number of recent Quaternary botanical studies where life-history and functional traits have been used to aid interpretation of long-term pollen records (e.g., Brussel et al., 2018; Connor et al., 2018; Carvalho et al., 2019; Van Der Sande et al., 2019). Application of traits to pollen-stratigraphical data is greatly hampered by the fact that many of the abundant pollen taxa can only be identified to genus (e.g., Quercus, Pinus) or family level (e.g., Poaceae). Relevant numerical tools for robust and statistically rigorous trait-analysis exist (e.g., Dray and Legendre, 2008; Ter Braak et al., 2012; Brown et al., 2014; Ter Braak, 2017, 2019; Ter Braak et al., 2017, 2018) but appropriate trait information is lacking for many of the fossil pollen taxa. The concept of traits for a large family such as Poaceae is currently unresolved. Van Der Sande et al. (2019) used phylogenetic signals to derive genus-level or even family-level mean trait values, whereas Connor et al. (2018) used traits of a representative plant species for a particular pollen type (e.g., Phleum phleoides for Poaceae, Torilis arvensis for Apiaceae). 
Rather surprisingly, traits have not been widely studied for plant-macrofossil assemblages (Birks, 2014) except for Bhagwat and Willis (2008; see above) and Jabłońska et al. (2019). The latter study centered on mesotrophic rich-fens and tested the hypothesis that fen stability is controlled by plant stress induced by waterlogging with calcium-rich but nutrient-poor groundwater. Thirteen traits or attributes for vascular plants and bryophytes identified from 32 European Holocene richfen macrofossil profiles were compiled. Traits and attributes considered included plant height, clonal spread, diaspore mass, specific leaf area, leaf dry matter, Ellenberg moisture values, and mycorrhizal status. Jabłońska et al. (2019) showed using their trait and attribute data that fens undergo a gradual autogenic process that may reduce fen resistance and enhance shifts to other mire types, explaining why long-lasting rich fens are a rare habitat type today (cf. Rybnícek, 1973). A study of Sphagnum-dominated mires in Poland involved macrofossils, testate amoebae, and mosses preserved in the peat (Lamentowicz et al., 2019) to detect a possible tipping-point in mire water-level. In this study, 15 functional traits for Sphagnum were compiled but, surprisingly, Sphagnum functional diversity (FD) remained very stable despite hydrological changes within the peatlands (Lamentowicz et al., 2019).

Various biochemical, morphological, and physiological "traits" have been used to reconstruct different aspects of the past environment based on Quaternary botanical fossils (Lomax and Fraser, 2015). Fossil pollen and spores can be used to quantify ultraviolet-B (UV-B) radiation flux through time using the concentration of UV-B-absorbing compounds preserved in fossil sporopollenin (Magri, 2011). This is a complex biopolymer and consists, in part, of para-coumaric acid ( $p \mathrm{CA}$ ) and ferulic acid. These compounds absorb UV-B (280-315 nm) and their abundance in pollen and spores increases in response to increasing UV-B flux (Rozema et al., 2001; Rozema et al., 2002; Blokker et al., 2006; Willis et al., 2011). The concentration of $p$ CA can be consistently estimated by a modified version of Thermally Assisted Hydrolysis and Methylation with pyrolysis Gas-Chromatography Mass-Spectroscopy (Seddon et al., 2017). Several attempts have been made to reconstruct changes in UV-B flux through historic and Holocene time (e.g., Rozema et al., 2001; Lomax et al., 2008; Willis et al., 2011; Jardine et al., 2016, 2020).

A second "trait" that is widely used to reconstruct past atmospheric $\mathrm{CO}_{2}$ concentrations is leaf stomatal density. It has long been known from experiments that many plants respond to increased $\mathrm{CO}_{2}$ by an increase in photosynthetic rate and a decrease in stomatal opening (Woodward, 1988). By examining herbarium specimens of leaves of eight temperate trees collected over the last 200 years, Woodward (1987) showed a 40\% decrease in stomatal density (stomata per unit leaf area) in response to increases in $\mathrm{CO}_{2}$ values from pre-industrial levels. Körner et al. (1979) and Woodward (1986) found that stomatal density often increased with elevation, In light of this work on stomatal numbers and atmospheric $\mathrm{CO}_{2}$ concentrations, Quaternary botanists measured stomatal density ( $\mathrm{SD}$ numbers $\mathrm{mm}^{-2}$ ) or stomatal index $[=\mathrm{SD} /(\mathrm{SD}+\mathrm{ED}) \times 100$ where $\mathrm{ED}$ is the epidermal cell density $\left(\mathrm{mm}^{-2}\right.$; Salisbury, 1927)] on fossil leaves of, for example, Salix herbacea, Betula nana, B. pendula, B. pubescens, and Quercus spp. To reconstruct past $\mathrm{CO}_{2}$ concentrations from these stomatal frequencies, stomatal density or index was measured for modern leaves collected at or grown under different $\mathrm{CO}_{2}$ levels to derive calibration functions between stomatal density or index and atmospheric $\mathrm{CO}_{2}$ concentration (e.g., Beerling et al., 1995; Rundgren and Beerling, 1999; Rundgren et al., 2005). These calibration functions have been used to estimate past $\mathrm{CO}_{2}$ concentrations in the last interglacial (e.g., Rundgren and Bennike, 2002; Rundgren et al., 2005), the last glacial maximum (e.g., Beerling and Chaloner, 1994), the lateglacial (e.g., Beerling et al., 1995; Rundgren and Björck, 2003), and the Holocene (e.g., Rundgren and Beerling, 1999; Wagner et al., 1999; Beerling and Rundgren, 2000; Rundgren and Björck, 2003; Jessen et al., 2007). The taxa used in these reconstructions in Europe have mainly been Salix herbacea (e.g., Beerling et al., 1995; Rundgren and Beerling, 1999; Rundgren and Bennike, 2002), Betula nana (e.g., Beerling, 1993; Rundgren and Björck, 2003; Finsinger and Wagner-Cremer, 2009; Steinthorsdottir et al., 2013), B. pubescens or B. pendula (e.g., Wagner et al., 1999; Wagner et al., 2002; Wagner et al., 2004; García-Amorena et al., 2008), Quercus robur or Q. petraea (e.g., Wagner et al., 2004; Van Hoof et al., 2006), S. cinerea (e.g., McElwain et al., 1995), or Buxus balearica and B. sempervirens (e.g., Rivera et al., 2014). In North America, needles of Pinus flexilis (e.g., Van Der Water et al., 1994), Larix laricina, Picea glauca, and P. mariana, and leaves of Dryas integrifolia (e.g., McElwain et al., 2002) have been used.

A recent study in eastern Australia (Hill et al., 2019) on leaves of Malaleuca quinquenervia did not find any relationship between stomatal density or index and $\mathrm{CO}_{2}$ concentration, temperature, or rainfall. Hill et al. (2019) concluded that stomatal numbers are a highly plastic "trait" in this flood-plain and lakeside tree and that stomatal changes may not reflect functional changes in the leaves.

An additional leaf "trait" that has been used in environmental reconstructions is the epidermal cell undulation index, which is a quantitative estimate of the degree of sinuosity of epidermal cell walls (Wagner-Cremer et al., 2010). It was developed as a means of reconstructing past changes in growing degree-days using fossil Betula nana leaves in northern Fennoscandia. The approach has recently been extended to mountain birch, B. pubescens ssp. czerepanovii (Ercan et al., 2020), which permits the use of the approach over much of Fennoscandia. It has not, as far as I know, been applied to fossil tree-birch leaves.

Relationships between leaf "traits" and their environment, particularly climate, have been discussed for over 100 years (e.g., Billings, 1905; Bailey and Sinnott, 1915, 1916). These relationships have been extensively explored and exploited in preQuaternary botany (see Peppe et al., 2018). Interest has recently focused on the leaf economic spectrum (LES) that provides a framework for leaf functional ecology (cf. Osnas et al., 2013). Vein networks are an important component of the LES. Many LES variables can easily be measured from modern leaves (e.g., Wang et al., 2020 but see Osnas et al., 2013), but they cannot be directly measured on fossil leaves (Peppe et al., 2018). Variables that can be measured on fossil leaves such as leaf area, petiole width, and vein density have been used to estimate critical LES variables such as leaf life-span, leaf mass per area, and 
carbon assimilation and respiration rates (Peppe et al., 2018). Although they are, in theory, applicable across many plant groups throughout the geological record, they do not appear to have been used in Quaternary botany.

A different set of leaf "traits" are organic biomarkers derived from leaf waxes. Such biomarkers are increasingly used as tools for reconstructing past environments (Berke, 2018). Organic geochemistry is a rapidly developing field and largely falls outside the scope of this paper. Within a leaf cuticle there is a matrix of cutin, a polyester biopolymer consisting of hydroxy fatty acids and waxes. The epicuticular wax layer contains $n$-alkanes and free and ester-bound long-chain $n$-alkyl wax lipids (Diefendorf et al., 2011). Leaf-wax composition and abundance can vary with ontogeny, environment, and among plant families, genera, species, and individuals. The isotopic composition of leaf-wax hydrogen $(\delta \mathrm{D})$ and of the stable carbon isotope composition of leaf-wax $\left(\delta^{13} \mathrm{C}\right)$ are increasingly used as proxies for changes in vegetation composition and density $\left(\mathrm{C}_{3} / \mathrm{C}_{4}\right.$ plants - e.g., Huang et al., 2006; Uno et al., 2016), precipitation (e.g., Huang et al., 1999; Sauer et al., 2001; Douglas et al., 2012; Garcin et al., 2012), and Arctic and temperate temperatures (e.g., Shuman et al., 2004; Thomas et al., 2012). Organic and isotope geochemistry are rapidly developing and complex research areas. A major challenge is to derive past environmental reconstructions from lake sediments whose organic material is derived from multiple sources including plankton, aquatic and terrestrial plants, as well as microbes (Huang et al., 2002). Bacterial cell membrane lipids such as branched glycerol dialkyl glycerol tetraethers appear to be nearly ubiquitous in lakes (e.g., Pearson et al., 2011). They have been used as an independent temperature proxy in Arctic Canada to evaluate the local colonization of dwarf Betula, as evidenced by sedimentary ancient DNA in relation to climate change (Crump et al., 2019). This study shows the potential of a multiproxy approach utilizing biogeochemical "traits" and molecular techniques such as ancient DNA. Further exciting advances in this type of study bridging biogeochemistry, Quaternary botany, and ancient DNA analyses can be expected in the next five to ten years.

Functional diversity (FD) is an important component of biodiversity that considers the range of functions that organisms perform in ecosystems (Hooper et al., 2002). It not only serves as a descriptor of an assemblage, but it can also be an indicator of ecosystem function. As FD is the diversity of taxon traits in an assemblage, it may capture information about traits that may be missing in measures of taxonomic richness or diversity (Birks et al., 2016). To date, very few Quaternary botanical studies have considered FD other than PFT diversity estimated from palynological data (e.g., Davis et al., 2015). Reitalu et al. (2015) explored in detail temporal patterns in FD as well as in taxonomic richness and evenness and phylogenetic diversity (PD) estimated from late-glacial and Holocene pollen data from 20 sites in Estonia and Latvia. They showed that shifts in FD and $\mathrm{PD}$ of the pollen data were closely related to climate change (as recorded in the Greenland NGRIP ice-core) and suggested that trait differences may have played an important role in long-term biotic responses to climate change. Human impact in the last 2000 years had a negative influence on FD and PD due to the decline of plant taxa with certain traits leading to functional convergence and the expansion of some taxa from particular phylogenetic lineages. In their study, Reitalu et al. (2015) faced the problem of assigning trait values to pollen taxa representing several plant species. For such taxa, they used a mean trait value for the species present in their study area for pollen taxa representing up to ten plant species. For pollen taxa with more than ten plant species, they used a random subset of species so that the number was approximately proportional to the total number of species in the Estonian flora belonging to that pollen taxon.

Clearly there is a need for critical comparisons of different estimation procedures for traits for pollen types to ascertain which procedures are robust and ecologically realistic. Given such procedures, there are exciting challenges in exploring simultaneously taxonomic, functional, and PD of modern and fossil pollen assemblages at a range of spatial and temporal scales.

\section{DISCUSSION AND CONCLUSION}

As documented above, there is a long history of ecological attributes (including traits) being used in Quaternary botany extending over nearly 120 years. The main use of attributes has been to aid in the reconstruction of past environments such as climate (e.g., Kühl, 2003), soil conditions (e.g., Felde and Birks, 2019), or vegetation (e.g., Zanon et al., 2018). Traits have also been used to investigate taxon responses to past environmental changes (e.g., Lacourse, 2009) or to generate hypotheses about the underlying drivers of past vegetation dynamics (e.g., Iversen, 1960).

The major limitations in using attributes or traits in Quaternary botany is the taxonomic level at which many Quaternary plant fossils, particularly pollen, and can be identified to (e.g., Reitalu et al., 2015). Identifications at the family or genus levels pose problems in the assignment of attribute or trait values to such taxa. Plant macrofossils have the advantage over pollen in that fossil seeds and fruits can often be identified to species level (Birks and Birks, 2000; Birks, 2001, 2003, 2014), thereby allowing an effective use of attributes such as indicator values with macrofossil assemblages (e.g., Felde and Birks, 2019). Despite detailed macrofossil identifications, traits have rarely been used in macrofossil studies (Birks, 2014), possibly because of some important limitations of macrofossil data, such as the abundance of zero values, mixed (nominal, qualitative, and quantitative) data types, and problems of false absences (=false negatives; Birks, 2014).

Enhancing interpretation of Quaternary botanical assemblages in terms of vegetational or ecosystem dynamics by means of attributes or traits demands that environmental reconstructions are available that are independent of the botanical assemblages (e.g., Birks and Birks, 2008; Lacourse, 2009; Reitalu et al., 2015). This demand avoids dangers of circular reasoning where changes in an assemblage are "explained" in terms of the traits of the taxa in the assemblage, just as assemblages should not be "explained" on the basis of the past 
environment inferred from the assemblage itself. Environmental reconstructions based on taxa, attributes, or traits are certainly valuable in some topics within paleoenvironmental research, but they should not be used to interpret or "explain" changes in the biological assemblages.

Reconstruction is a form of description in paleoecology ("descriptive and narrative approaches"-Birks and Berglund, 2018) whereas the testing of explicit hypotheses about the underlying "drivers" or processes behind the observed patterns in assemblages ("analytical approach"-Birks and Berglund, 2018) often requires not only assemblage data ("responses") but also independent environmental data ("predictors"; e.g., Birks and Birks, 2006; Birks, 2008; Crump et al., 2019). Major methodological advances are being made in other branches of Quaternary science to reconstruct different aspects of the past environment using, for example, biomarkers (e.g., Pearson et al., 2011; Crump et al., 2019), and stable isotopes (e.g., Colombaroli et al., 2016). Such independent environmental reconstructions will allow ecological attributes and traits to be used to further the interpretation of past biotic changes, along the lines pioneered by Iversen (1960), Lacourse (2009), and Reitalu et al. (2015). Novel approaches for defining ecological traits at broad spatial scales are also being developed (e.g., Ustin and Gamon, 2010; He et al., 2019) that are directly relevant to the spatial scale of regional pollen stratigraphies (Birks, 2019).

Ecological attributes and traits are potentially useful tools in Quaternary botany but they are no substitute for a good ecological knowledge of the taxa found in assemblages. Faegri (1966) proposed in his discussion of the interpretation of pollen assemblages "it presumes a very intimate knowledge of the ecology and sociology of the vegetation types concerned.... pollen analysis of any vegetation types without such knowledge is bound to become at its best a lifeless stratigraphical tool, at its worst useless altogether," The role of species identity is one of the biggest challenges for any understanding of plant responses, past, present, or future to the environment (Clark, 2008). Clark (2016) showed, using forest data from eastern North America, that an "analysis of species better explains and predicts traits than does direct analysis of the traits themselves; trait data contain less, not more, information than species on environmental responses."

Despite the great upsurge of interest in trait-based ecology in recent decades, in Quaternary botany the use of attributes and traits has been and remains an integral part of the interpretation of botanical assemblages in terms of past vegetation or environmental change or in the reconstruction of past environments. There seems little prospect of (or need

\section{REFERENCES}

Andersson, G. (1902). Hasseln i Sverige Fordom och nu, Vol. 3. Stockholm: Sveriges Geologiska Undersökning, 1-168

Andersson, G. (1903). Klimatet i Sverige etter istiden. Nordisk Tidsskrift 1, 1-26.

Andersson, G. (1909). The climate of Sweden in the Late-Quaternary period. Facts and theories. Sverig. Geol. Unders. Ser. C Årbok 3, 1-88. doi: 10.1038/ nature 12921

Atkinson, T. C., Briffa, K. R., Coope, G. R., Joachim, M., and Perry, D. (1986). "Climatic calibration of coleopteran data," in Handbook of Holocene for) a "new" Quaternary botany or paleoecology based on traits. Quaternary botany, by necessity, follows what McGill et al. (2006) called "a nomenclatural approach by focusing on species identities," which they proposed "has resulted in a loss of ecological generality." They argued that "statements about traits give generality and predictability, whereas nomenclatural ecology tends toward contingent rules and special cases." Only time will tell if this search for the "Holy Grail" in ecology will fulfill the exciting proposals of trait-based ecology and "clean up the "mess"' of community ecology (McGill et al., 2006) and if this approach will contribute to more refined interpretations of Quaternary botanical data and improve our understanding of long-term vegetation and ecosystem dynamics.

Bradshaw (1987) emphasized in his discussion of different approaches to plant ecology that "at any point of time, any discipline in science tends to be seized by a particular methodology or enthusiasm and other approaches get 'dumped'. So it is in ecology-although because of obstinate individualism, nothing is ever completely forgotten." The contrast between the rapid upsurge of interest in trait-based ecology in the last 1520 years and the use of attributes and traits in Quaternary botany over the last 120 years reinforce Bradshaw's perceptive comment.

\section{AUTHOR CONTRIBUTIONS}

The author confirms being the sole contributor of this work and has approved it for publication.

\section{FUNDING}

This work was supported by the European Research Council (ERC) under the European Union's Horizon 2020 research and innovation program (Grant Agreement No. 741413) HOPE: Humans on Planet Earth-Long-term impacts on biosphere dynamics.

\section{ACKNOWLEDGMENTS}

I am indebted to Hilary Birks, Vivian Felde, Mark Hill, Cajo ter Braak, and Ole Reidar Vetaas for discussions about ecological attributes and traits; to Cathy Jenks for help in the preparation of this manuscript; to the two reviewers for their valuable comments and suggestions; and to the Editors of this Research Topic for the invitation to contribute to this Topic.

Palaeoecology and Palaeohydrology, ed. B. E. Berglund (New York, NY: John Wiley \& Sons), 851-858.

Bailey, I. W., and Sinnott, E. W. (1915). A botanical index of Cretaceous and Tertiary climates. Science 41, 831-834. doi: 10.1126/science.41.10 66.831

Bailey, I. W., and Sinnott, E. W. (1916). The climatic distribution of certain types of angiosperm leaves. Am. J. Bot. 3, 24-39. doi: 10.1002/j.1537-2197.1916. tb05397.x

Barboni, D., Harrison, S. P., Bartlein, P. J., Jalut, G., New, M., Prentice, I. C., et al. (2004). Relationships between plant traits and climate in the Mediterranean 
region: a pollen data analysis. J. Veg. Sci. 15, 635-646. doi: 10.1111/j.1654-1103. 2004.tb02305.x

Bartelheimer, M., and Poschlod, P. (2016). Functional characterizations of Ellenberg indicator values - a review on ecophysiological determinants. Fun. Ecol. 30, 506-516. doi: 10.1111/1365-2435.12531

Beale, C. M., Lennon, J. J., and Gimona, A. (2008). Opening the climate envelope reveals no macroscale associations with climate in European birds. Proc. Natl. Acad. Sci. U.S.A. 105, 14908-14912. doi: 10.1073/pnas.080350 6105

Beerling, D. J. (1993). Changes in the stomatal density of Betula nana leaves in response to increases in atmospheric carbon dioxide concentration since the late-glacial. Spec. Pap. Palaeontol. 49, 181-187.

Beerling, D. J., Birks, H. H., and Woodward, F. I. (1995). Rapid late-glacial atmospheric $\mathrm{CO}_{2}$ changes reconstructed from the stomatal density record of fossil leaves. J. Quat. Sci. 10, 379-384. doi: 10.1002/jqs.3390100407

Beerling, D. J., and Chaloner, W. G. (1994). Atmospheric $\mathrm{CO}_{2}$ changes since the last glacial maximum: evidence from the stomatal density record of fossil leaves. Rev. Palaeobot. Palynol. 81, 11-17. doi: 10.1016/0034-6667(94)90123-6

Beerling, D. J., and Rundgren, M. (2000). Leaf metabolic and morphological responses of dwarf willow (Salix herbacea) in the sub-arctic to the past 9000 years of global environmental change. New Phytol. 145, 257-269. doi: 10.1046/ j.1469-8137.2000.00582.x

Bennie, J., Hill, M. O., Baxter, R., and Huntley, B. (2006). Influence of slope and aspect on long-term vegetation change in British chalk grasslands. J. Ecol. 94, 355-368. doi: 10.1111/j.1365-2745.2006.01104.x

Berke, M. A. (2018). "Reconstructing terrestrial paleoenvironments using sedimentary organic biomarkers," in Methods in Paleoecology: Reconstructing Cenozoic Terrestrial Environments and Ecological Communities, eds D. A. Croft, D. F. Su, and S. W. Simpson (Cham: Springer), 121-149. doi: 10.1007/978-3319-94265-0_8

Bernhardt-Römermann, M., Römermann, C., Nuske, R., Parth, A., Klotz, S., Schmidt, W., et al. (2008). On the identification of the most suitable traits for plant functional trait analyses. Oikos 117, 1533-1541. doi: 10.1111/j.0030-1299. 2008.16776.x

Bhagwat, S. A., and Willis, K. J. (2008). Species persistence in northerly glacial refugia of Europe: a matter of chance or biogeographical traits? J. Biogeogr. 35, 464-482. doi: 10.1111/j.1365-2699.2007.01861.x

Billings, F. H. (1905). Precursory leaf serrations of Ulmus. Botan. Gazette 40, 224-225. doi: $10.1086 / 328669$

Birks, H. H. (2001). "Plant macrofossils," in Tracking Environmental Change Using Lake Sediments volume 3: Terrestrial, Algal, and Siliceous Indicators, eds J. P. Smol, H. J. B. Birks, and W. M. Last (Dordrecht: Kluwer), 49-74.

Birks, H. H. (2003). The importance of plant macrofossils in the reconstruction of Lateglacial vegetation and climate: examples from Scotland, western Norway, and Minnesota. USA. Quat. Sci. Rev. 22, 453-473. doi: 10.1016/s0277-3791(02) 00248-2

Birks, H. H. (2013). "Plant macrofossils: Introduction," in Encyclopedia of Quaternary Science, 2nd Edn, eds S. A. Elias and C. J. Mock (Amsterdam: Elsevier), 593-612.

Birks, H. H., and Birks, H. J. B. (2000). Future uses of pollen analysis must include plant macrofossils. J. Biogeogr. 27, 31-35. doi: 10.1046/j.1365-2699.2000. 00375.x

Birks, H. H., and Birks, H. J. B. (2006). Multi-proxy studies in palaeolimnology. Veget. History Archaeobot. 15, 235-251. doi: 10.1007/s00334-006-0066-6

Birks, H. J. B. (1986). "Late Quaternary biotic changes in terrestrial and limnic environments, with particular reference to north west Europe," in Handbook of Holocene Palaeoecology and Palaeohydrology, ed. B. E. Berglund (Chichester: J Wiley \& Sons), 3-65.

Birks, H. J. B. (1990). Indicator values of pollen types from post 6000 B.P. pollen assemblages from southern England and southern Sweden. Quat. Stud. Poland 10, 21-31.

Birks, H. J. B. (2008). "Holocene climate research - progress, paradigms, and problems," in Climate Variability and Global Warming: A Holocene Perspective, eds R. W. Battarbee and H. Binney (Oxford: Wiley-Blackwell), 7-57. doi: 10. 1002/9781444300932.ch2

Birks, H. J. B. (2014). Challenges in the presentation and analysis of plantmacrofossil stratigraphical data. Veget. History Archaeobot. 23, 309-330. doi: 10.1007/s00334-013-0430-2
Birks, H. J. B. (2019). Contributions of Quaternary botany to modern ecology and biogeography. Plant Ecology and Diversity 12, 189-385. doi: 10.1080/17550874. 2019.1646831

Birks, H. J. B., and Berglund, B. E. (2018). One hundred years of Quaternary pollen analysis 1916-2016. Veget. Hist. Archaeobot. 27, 271-309. doi: 10.1007/s00334017-0630-2

Birks, H. J. B., and Birks, H. H. (2004). The rise and fall of forests. Science 305, 484-485. doi: 10.1126/science. 1101357

Birks, H. J. B., and Birks, H. H. (2008). Biological responses to rapid climate changes at the Younger Dryas-Holocene transition at Kråkenes, western Norway. Holocene 18, 19-30. doi: 10.1177/0959683607085572

Birks, H. J. B., Felde, V. A., Bjune, A. E., Seppä, H., and Giesecke, T. (2016). Does pollen-assemblage richness reflect floristic richness? A review of recent developments and future challenges. Rev. Palaeobot. Palynol. 228, 1-25. doi: 10.1016/j.revpalbo.2015.12.011

Birks, H. J. B., Heiri, O., Seppä, H., and Bjune, A. E. (2010). Strengths and weaknesses of quantitative climate reconstructions based on Late-Quaternary biological proxies. Open Ecol J. 3, 68-110. doi: 10.7892/boris.10005

Birks, H. J. B., and Willis, K. J. (2008). Alpines, trees, and refugia in Europe. Plant Ecol. Divers. 1, 147-160. doi: 10.1080/17550870802349146

Blackman, V. H. (1920). The significance of the efficiency index of plant growth. New Phytol. 19, 97-100. doi: 10.1111/j.1469-8137.1920.tb07320.x

Blokker, P., Boelen, P., Broekman, R., and Rozema, J. (2006). The occurrence of $p$-coumaric acid and ferulic acid in fossil plant materials and their use as UV-proxy. Plant Ecol. 182:197. doi: 10.1007/s11258-005-9026-y

Bloom, A. J., Chapin, F. S., and Mooney, H. A. (1985). Resource limitation in plants - an economic analogy. Ann. Rev. Ecol. Syst. 16, 363-392. doi: 10.1146/annurev. es.16.110185.002051

Bradshaw, A. D. (1987). Comparison - its scope and limits. New Phytol. 106, 3-21. doi: 10.1111/j.1469-8137.1987.tb04679.x

Brewer, S., Guiot, J., Sánchez-Goñi, M. F., and Klotz, S. (2008). The climate in Europe during the Eemian: a multi-method approach using pollen data. Quat. Sci. Rev. 27, 2303-2315. doi: 10.1016/j.quascirev.2008.08.029

Brown, A. M., Warton, D. I., Andrew, N. R., Binns, M., Cassis, G., and Gibb, H. (2014). The fourth-corner solution - using predictive models to understand how species traits interact with the environment. Methods Ecol. Evol. 5, 344352. doi: 10.1111/2041-210x.12163

Brussel, T., Minckley, T. A., Brewer, S. C., and Long, C. J. (2018). Community-level functional interactions with fire track long-term structural development and fire adaptation. J. Veg. Sci. 29, 450-458. doi: 10.1111/jvs. 12654

Cadotte, M. W., Arnillas, C. A., Livingstone, S. W., and Yasui, S.-L. E. (2015). Predicting communities from functional traits. Trends Ecol. Evol. 30, 510-511. doi: 10.1016/j.tree.2015.07.001

Cappers, R. T. J. (1993/1994). Botanical macro-remains of vascular plants of the Heveskesklooster Terp (The Netherlands) as tools to characterize the past environment. Palaeohistoria 3, 107-167.

Carvalho, F. A., Brown, K. A., Waller, M. P., Bunting, M. J., Boom, A., and Leng, M. J. (2019). A method for reconstructing temporal changes in vegetation functional trait composition using Holocene pollen assemblages. PLoS One 14:e0216698. doi: 10.1371/journal.pone.0216698

Chevalier, M. (2019). Enabling possibilities to quantify past climate from fossil assemblages. Glob. Planet. Change 15, 27-35. doi: 10.1016/gloplacha.2019. 01.016

Chevalier, M., and Chase, B. M. (2015). Southeast African records reveal a coherent shift from high- to low-latitude forcing mechanisms along the east African margin across last glacial interglacial transition. Quat. Sci. Rev. 125, 117-130. doi: 10.106/j.quascirev.2015.07.089

Chevalier, M., Cheddadi, R., and Chase, B. M. (2014). CREST (Climate Reconstruction SofTware): a probability density function (PDF)-based quantitative climate reconstruction method. Clim. Past 10, 2081-2098. doi: $10.5194 / \mathrm{cp}-10-2081-2014$

Clark, J. S. (2008). Beyond neutral science. Trends Ecol. Evol. 24, 8-15. doi: 10.1016/ j.tree.2008.09.004

Clark, J. S. (2016). Why species tell more about traits than traits about species: predictive analysis. Ecology 97, 1979-1993. doi: 10.1002/ecy.1453

Collins, P. M., Davis, B. A. S., and Kaplan, J. O. (2012). The mid-Holocene vegetation of the Mediterranean region and southern Europe, and comparison 
with the present day. J. Biogeogr. 39, 1848-1861. doi: 10.1111/j.1365-2699.2012. 02738.x

Colombaroli, D., Cherubini, P., De Ridder, M., and Saurer, M. (2016). Stable carbon and oxygen isotopes in tree rings show physiological responses of Pericopsis elata to precipitation in the Congo Basin. J. Trop. Ecol. 32, 213-225. doi: 10. $1017 /$ S0266467416000134

Connor, S. E., Colombaroli, D., Confortini, F., Gobet, E., Ilyashuk, B. P., Ilyashuk, E. A., et al. (2018). Long-term population dynamics: theory and reality in a peatland ecosystem. J. Ecol. 106, 333-346. doi: 10.1111/1365-2745.12865

Cornwell, W. K., and Grubb, P. J. (2003). Regional and local patterns in plant species richness with respect to resource availability. Oikos 100, 417-428. doi: 10.1034/j.1600-0706.2003.11697.x

Crump, S. E., Miller, G. H., Power, M., Sepúlveda, J., Dildar, N., Coghlan, M., et al. (2019). Arctic shrub colonization lagged peak postglacial warmth: Molecular evidence in lake sediment from Arctic Canada. Glob. Change Biol. 25, 42444256. doi: $10.1111 / \mathrm{gcb} .14836$

Davis, B. A. S., Brewer, S., Stevenson, A. C., Guiot, J., and Data Contributors (2003). The temperature of Europe during the Holocene reconstructed from pollen data. Quat. Sci. Rev. 22, 1701-1716. doi: 10.1016/S0277-3791(03)00173-2

Davis, B. A. S., Collins, P. M., and Kaplan, J. O. (2015). The age and post-glacial development of the modern European vegetation: a plant functional approach based on pollen data. Veg. Hist. Archaeobot. 24, 303-317. doi: 10.1007/s00334014-0476-9

Diaz, S., Hodgson, J. G., Thompson, K., Cabido, M., Cornelissen, J. H. C., Jalili, A., et al. (2004). The plant traits that drive ecosytems: evidence from three continents. J. Veg. Sci. 15, 295-304.

Diefendorf, A. F., Freeman, K. H., Wing, S. L., and Graham, H. V. (2011). Production of $n$-alkyl lipids in living plants and implications for the geologic past. Geochim Cosmochim. Acta 75, 7472-7485. doi: 10.1016/j.gca.2011.09.028

Diekmann, M. (2003). Species indicator values as an important tool in applied plant ecology - a review. Basic Appl. Ecol. 4, 493-506. doi: 10.1078/1439-1791-00185

Díaz, S., and Cabido, M. (2001). Vive la différence: plant functional diversity matters to ecosystem processes. Trends Ecol. Evol. 16, 646-655. doi: 10.1016/ S0169-5347(01)02283-2

Dolédec, S., Chessel, D., ter Braak, C. J. F., and Champely, S. (1996). Matching species traits to environmental variables: a new three-table ordination method. Environ. Ecol. Stat. 3, 143-166. doi: 10.1007/bf02427859

Dormann, C. F. (2007). Promising the future? Global change projections of species distributions. Basic Appl. Ecol. 8, 387-397. doi: 10.1016/j.baae.2006.11.001

Douglas, P. M. J., Pagani, M., Brenner, M., Hodell, D. A., and Curtis, J. H. (2012). Aridity and vegetation composition are important determinants of leaf-wax $\delta \mathrm{D}$ values in southeastern Mexico and Central America. Geochim. Cosmochim. Acta 97, 24-45. doi: 10.1016/j.gca.2012.09.005

Dray, S., and Legendre, P. (2008). Testing the species traits-environment relationships: the fourth-corner problem revisited. Ecology 89, 3400-3412. doi: 10.1890/08-0349.1

Dzwonko, Z. (2001). Assessment of light and soil conditions in ancient and recent woodlands by Ellenberg indicator values. J. Appl. Ecol. 38, 942-951. doi: 10. 1046/j.1365-2664.2001.00649.x

Ellenberg, H. (1948). Unkrautgesellschaften als Mass für den Säuregrad, die Verdichtung und anders Eigenschaften des Ackerbodens. Berich. Über Landtechn. Kurator. Tachn. Bauwes. Landwirt. 4, 130-146.

Ellenberg, H., Weber, H. E., Düll, R., Wirth, V., Werner, W., and Paulissen, D. (1992). Zeigerwerte von Pflanzen in Mitteleuropa, Vol. 18. Göttingen: Goltze, 1-248.

Enevold, R., Rasmussen, P., Løvschal, M., Olsen, J., and Odgaard, B. V. (2019). Circumstantial evidence of non-pollen palynomorph palaeoecology: a 5,500 year NPP record from forest hollow sediments compared to pollen and macrofossil inferred palaeoenvironments. Veg. History Archaeobot. 28, 105121. doi: 10.1007/s00334-018-0687-6

Ercan, F. E. Z., De Boer, H. J., and Wagner-Cremer, F. (2020). A growing degree day inference model based on mountain birch leaf cuticle analysis over a latitudinal gradient in Fennoscandia. Holocene 30, 344-349. doi: 10.1177/ 0959683619865605

Faegri, K. (1950). On the value of palaeoclimatological evidence. Cent. Proc. $R$. Meteorolo. Soc. 1950, 188-195.

Faegri, K. (1966). Some problems of representivity in pollen analysis. Palaeobotanist 15, 135-140.
Faegri, K., and Iversen, J. (1950). Text-book of Modern Pollen Analysis. Copenhagen: Munksgaard.

Felde, V. A., and Birks, H. H. (2019). Using species attributes to characterize lateglacial and early-Holocene environments at Kråkenes, western Norway. J. Veg. Sci. 30, 1228-1238. doi: 10.1111/jvs.12804

Finsinger, W., and Wagner-Cremer, F. (2009). Stomatal-based inference models for reconstruction of atmospheric $\mathrm{CO}_{2}$ concentration: a method assessment using a calibration and validation approach. Holocene 19, 757-764. doi: 10. $1177 / 0959683609105300$

Firbas, F., and Preuss, H. (1934). Über die Bestimmung der Walddichte und der Vegetation waldloser Gebeite mit Hilfe der Pollenanalyse. Planta 22, 109-145. doi: 10.1007/BF01916514

Fournier, B., Lara, E., Jassey, V. E. J., and Mitchell, E. A. D. (2015). Functional traits as a new approach for interpreting testate amoeba palaeo-records in peatlands and assessing the causes and consequences of past changes in species composition. Holocene 25, 1375-1383. doi: 10.1177/0959683615585842

Franklin, J. (2010). Mapping Species Distributions - Spatial Inference and Prediction. Cambridge: Cambridge University Press.

Funk, J. L., Larson, J. E., Ames, G. M., Butterfield, B. J., Cavender-Bares, J., Firn, J., et al. (2017). Revisiting the Holy Grail: using plant functional traits to understand ecological processes. Biol. Rev. 92, 1156-1173. doi: 10.1111/brv. 12275

Fyfe, R. M., Roberts, N., and Woodbridge, J. (2010). A pollen-based pseudobiomisation approach to anthropogenic land-cover change. Holocene 20, 1165-1171. doi: 10.1177/0959683610369509

Gachet, S., Brewer, S., Cheddadi, R., Davis, B. A. S., Gritti, E., and Guiot, J. (2003). A probabilistic approach to the use of pollen indicators for plant attributes and biomes: an application to European vegetation at 0 and $6 \mathrm{ka}$. Glob. Ecol. Biogeogr. 12, 103-118. doi: 10.1046/j.1466-822X.2003.00311.x

García-Amorena, I., Wagner-Cremer, F., Gomez Manzaneque, F., van Hoof, T. B., García Alvarez, S., and Visscher, H. (2008). $\mathrm{CO}_{2}$ radiative forcing during the Holocene Thermal Maximum revealed by stomatal frequency of Iberian oak leaves. Biogeosci. Discuss. 5, 3945-3964. doi: 10.5194/bgd-5-39452008

Garcin, Y., Schwab, V. F., Gleixner, G., Kahmen, A., Todou, G., Séné, O., et al. (2012). Hydrogen isotope ratios of lacustrine sedimentary n-alkanes as proxies of tropical African hydrology: Insights from a calibration transect across Cameroon. Geochim. Cosmochim. Acta 79, 106-126. doi: 10.1016/j.gca.2011. 11.039

Garnier, E., Navas, M.-L., and Grigulis, K. (2016). Plant Functional Diversity. Organism Traits, Community Structure, and Ecosystem Properties. Oxford: Oxford University Press.

Godefroid, S., and Dana, E. D. (2007). Can Ellenberg's indicator values for Mediterranean plants be used outside their region of definition? J. Biogeogr. 34, 62-68. doi: 10.1111/j.1365-2699.2006.01582.x

Grime, J. P. (1979). Plant Strategies and Vegetation Processes. Chichester: J Wiley \& Sons.

Grime, J. P. (2001). Plant Strategies, Vegetation Processes, and Ecosystem Properties. Chichester: J. Wiley \& Sons.

Grinnell, J. (1917). The niche-relationships of the Californian Thrasher. Auk 34, 427-433. doi: 10.2307/4072271

Grubb, P. J. (1977). The maintenance of species-richness in plant communities: The importance of the regeneration niche. Biol. Rev. 52, 107-145. doi: 10.1111/ j.1469-185x.1977.tb01347.x

Guisan, A. (2014). Predictive traits to the rescue. Nat. Climate Change 4, 175-176. doi: $10.1038 /$ nclimate2157

Hawkes, J. C., Pyatt, D. G., and White, I. M. S. (1997). Using Ellenberg indicator values to assess soil quality in British forests from ground vegetation: a pilot study. J. Appl. Ecol. 34, 375-387.

He, N., Liu, C., Piao, S., Sack, L., Xu, L., Luo, Y., et al. (2019). Ecosystem traits linking functional traits to macroecology. Trends Ecol. Evol. 34, 200-210. doi: 10.1016/j.tree.2018.11.004

Hellegers, M., Ozinga, W. A., Hinsberg van, A., Huijbregts, M. A. J., Hennekens, S. M., Schaminée, J. H. J., et al. (2020). Evaluating the ecological realism of plant species distribution models with ecological indicator values. Ecography 43, 161-170. doi: 10.1111/ecog.04291

Hill, K. E., Barr, C., Tibby, J., Hill, R. S., and Watling, J. R. (2019). A comparison of stomatal traits between contemporary and fossil leaves of Melaleuca 
quinquenervia: Do they reflect climate variation? Rev. Palaeobot. Palynol. 271:104109. doi: 10.1016/j.revpalbo.2019.104109

Hill, M. O., and Carey, P. D. (1997). Prediction of yield in the Rothamsted Park Grass Experiment by Ellenberg indicator values. J. Veg. Sci. 8, 579-586. doi: $10.2307 / 3237210$

Hill, M. O., Preston, C. D., Bosanquet, S. D. S., and Roy, D. B. (2007). BRYOATTAttributes of British and Irish mosses, liverworts and hornworts. Huntingdon: Centre for Ecology and Hydrology.

Hill, M. O., Preston, C. D., and Roy, D. B. (2004). PLANTATT - Attributes of British and Irish Plants: status, size, life history, geography and habitats. Huntingdon: Centre for Ecology \& Hydrology.

Hill, M. O., Roy, D. B., Mountford, J. O., and Bunce, R. G. H. (2000). Extending Ellenberg's indicator values to a new area: an algorithmic approach. J. Appl. Ecol. 37, 3-15. doi: 10.1046/j.1365-2664.2000.00466.x

Holtland, W. J., ter Braak, C. J. F., and Schouten, M. G. C. (2010). Iteratio: calculating environmental indicator values for species and relevés. Appl. Veg. Sci. 13, 369-377. doi: 10.1111/j.1654-109X.2009.01069.x

Hooper, D. U., Solan, M., Symstad, A., Díaz, S., Gessner, M. O., Buchmann, N., et al. (2002). "Species diversity, functional diversity, and ecosystem functioning," in Biodiversity and Ecosystem Functioning, eds M. Loreau, S. Naeem, and P. Inchausti (Oxford: Oxford University Press), 195-208.

Huang, Y., Shuman, B., Wang, Y., Webb, T., Grimm, E. C., and Jacobson, G. L. (2006). Climatic and environmental controls on the variation of $C_{3}$ and $C_{4}$ plant abundances in central Florida for the past 62,000 years. Palaeogeogr. Palaeoclimatol. Palaeoecol. 237, 428-435. doi: 10.1016/j.palaeo.2005.12.014

Huang, Y., Shuman, B., Yang, Y., and Webb, T. (2002). Hydrogen isotope ratios of palmitic acid in lacustrine sediments record late Quaternary climate variations. Geology 30, 1103-1106.

Huang, Y., Street-Perrott, F. A., Perrott, R. A., Metzger, P., and Eglinton, G. (1999). Glacial-interglacial environmental changes inferred from molecular and compound-specific $\delta^{13} \mathrm{C}$ analyses of sediments from Sacred Lake. Mt. Kenya. Geochim. Cosmochim. Acta 63, 1383-1404. doi: 10.1016/S0016-7037(99) 00074-5

Iversen, J. (1936). Biologische Pflanzentypen als Hilfsmittel in der Vegetationforschung. Ein Beitrag zur ökologischer Charakterisierung und Anordnung der Pflanzengesellshaften. Doctoral thesis, University of Copenhagen, Copenhagen.

Iversen, J. (1941). Land occupation in Denmark's Stone Age. Danmarks Geol. Unders. II 66, 1-68.

Iversen, J. (1944). Viscum, Hedera and Ilex as climate indicators. A contribution to the study of the post-glacial temperature climate. Geol. Fören. Stock. Förhand. 66, 463-483. doi: 10.1080/11035894409445689

Iversen, J. (1949). The influence of prehistoric man on vegetation. Danmarks Geol. Unders. IV 3, 1-25.

Iversen, J. (1954). The Late-glacial flora of Denmark and its relation to climate and soil. Danmarks Geol. Unders. II 80, 87-119.

Iversen, J. (1958). The bearing of glacial and interglacial epochs on the formation and extinction of plant taxa. Systematics of today. Uppsala Univ. Arsskrift 6, $210-215$.

Iversen, J. (1960). Problems of the early post-glacial forest development in Denmark. Danmarks Geol. Unders. IV 4, 1-32.

Iversen, J. (1973). The Development of Denmark's Nature Since the Last Glacial. Danmarks geologiske. København: C.A. Reitzels Forlag, 1-126

Jabłońska, E., Michaelis, D., Tokarska, M., Goldstein, K., Grygoruk, M., Wilk, M., et al. (2019). Alleviation of plant stress precedes termination of rich fen stages in peat profiles of lowland mires. Ecosystems doi: 10.1007/s10021-019-00437-y

Jardine, P. E., Fraser, W. T., Gosling, W. D., Roberts, C. N., Eastwood, W. J., and Lomax, B. H. (2020). Proxy reconstruction of ultraviolet-B irradiance at the Earth's surface, and its relationship with solar activity and ozone thickness. Holocene 30, 155-161. doi: 10.1177/0959683619875798

Jardine, P. E., Fraser, W. T., Lomax, B. H., Sephton, M. A., Shanahan, T. M., Miller, C. S., et al. (2016). Pollen and spores as biological recorders of past ultraviolet irradiance. Sci. Rep. 6:39269. doi: 10.1038/srep39269

Jensen, P. B. (1910). Studier over Skovtrærnes Forhold til Lyset. Tidsskr. Skovvæesen $22,1-116$

Jensen, P. B. (1949). Causal plant-geography. Det Kong. Dans. Videnskab. Selsk. Biol. Meddel. 21, 1-19.

Jessen, C. A., Rundgren, M., Björck, S., and Muscheler, R. (2007). Climate forced atmospheric $\mathrm{CO}_{2}$ variability in the early Holocene: A stomatal frequency reconstruction. Glob. Planet. Change 57, 247-260. doi: 10.1016/j.gloplacha. 2006.11.035

Jonsgard, B., and Birks, H. H. (1995). Late-glacial mosses and environmental reconstructions at Kråkenes, western Norway. Lindbergia 20, 64-82.

Jurado, E., Westoboy, M., and Nelson, D. (1991). Diaspore weight, dispersal, growth form and perenniality of central Astralian plants. J. Ecol. 79, 811-830.

Kollmann, J., and Fischer, A. (2003). Vegetation as indicator for habitat quality. Basic Appl. Ecol. 4, 489-491. doi: 10.1078/1439-1791-00209

Körner, C. (2018). Concepts in empirical plant ecology. Plant Ecol. Diver. 11, 405-428. doi: 10.1080/17550874.2018.1540021

Körner, C., Scheel, J. A., and Bauer, H. (1979). Maximum leaf diffusive conductance in vascular plants. Photosynthetica $13,45-82$.

Kühl, N. (2003). Der Bestimmung botanisch-klimatolgischer Transferfunktion und die Rekonstruktion der hodennahen Klimazustandes in Europa wähend der Eem-Warmzeit. Dissertat. Bot. 375, 1-149

Kühl, N., Gebhardt, C., Litt, T., and Hense, A. (2002). Probability density functions as botanical-climatological transfer functions for climate reconstruction. Q. Res. 58, 381-392. doi: 10.1006/qres.2002.2380

Kühl, N., and Gobet, E. (2010). Climate evolution during the Middle Pleistocene warm period of Bilshausen. Germany, compared to the Holocene. Q. Sci. Rev. 29, 3736-3749. doi: 10.1016/j.quascirev.2010.08.006

Kühl, N., and Litt, T. (2003). Quantitative time series reconstruction of Eemian temperature at three European sites using pollen data. Veg. History Archaeobot. 12, 205-214. doi: 10.1007/s00334-003-0019-2

Kuneš, P., Odgaard, B. V., and Gaillard, M. J. (2011). Soil phosphorus as a control of productivity and openness in temperate interglacial forest ecosystems. J. Biogeogr. 38, 2150-2164. doi: 10.1111/j.1365-2699.2011.02557.x

Lacourse, T. (2009). Environmental change controls postglacial forest dynamics through interspecific differences in life-history traits. Ecology 90, 2149-2160. doi: 10.1890/08-1136.1

Lamentowicz, M., Gałka, M., Lamentowicz, Ł, Obremska, M., Kühl, N., Lücke, A., et al. (2015). Reconstructing climate change and ombrotrophic bog development during the last 4000 years in northern Poland using biotic proxies, stable isotopes and trait-based approach. Palaeogeogr. Palaeoclimatol. Palaeoecol. 418, 261-277. doi: 10.1016/j.palaeo.2014.11.015

Lamentowicz, M., Gałka, M., Marcisz, K., Słoński, M., Kajukało-Drygalska, K., Dayras, M. D., et al. (2019). Unveiling tipping points in long-term ecological records from Sphagnum-dominated peatlands. Biol. Lett. 15:20190043. doi: 10. 1098/rsbl.2019.0043

Lavorel, S., and Garnier, E. (2002). Predicting changes in community composition and ecosystem functioning from plant traits: revisiting the Holy Grail. Funct. Ecol. 16, 545-556. doi: 10.1046/j.1365-2435.2002.00664.x

Lawesson, J. E., Fosaa, A. M., and Olsen, E. (2003). Calibration of Ellenberg indicator values for the Faroe Islands. Appl. Veget. Sci. 6, 53-62. doi: 10.1111/j. 1654-109X.2003.tb00564.x

Legendre, P., Galzin, R., and Harmelin-Vivien, M.-L. (1997). Relating behaviour to habitat: solutions to the fourth-corner problem. Ecology 78, 547-562. doi: 10.1890/0012-9658(1997)078[0547:rbthst]2.0.co;2

Leishman, M. R., and Westoby, M. (1992). Classifying plants into groups on the basis of associations of individual traits - evidence from Australian semi-arid woodlands. J. Ecol. 80, 417-424.

Litt, T., Schölzel, C., Kühl, N., and Brauer, A. (2009). Vegetation and climate history in the Westeifel Volcanic Field (Germany) during the last 11,000 years based on annually laminated lacustrine maar sediments. Boreas 38, 679-690. doi: 10.1111/j.1502-3885.2009.00096.x

Lomax, B. H., and Fraser, W. T. (2015). Palaeoproxies: botanical monitors and recorders of atmospheric change. Palaeontology 58, 759-768. doi: 10.1111/pala. 12180

Lomax, B. H., Fraser, W. T., Sephton, M. A., Callaghan, T. V., Self, S., Harfoot, M., et al. (2008). Plant spore walls as a record of long-term changes in ultraviolet-B radiation. Nat. Geosci. 1, 592-596. doi: 10.1038/ ngeo 278

Magri, D. (2011). Past UV-B flux from fossil pollen: prospects for climate, environment and evolution. New Phytol. 192, 310-312. doi: 10.1111/j.14698137.2011.03864.x

Marcisz, K., Colombaroli, D., Jassey, V. E. J., Tinner, W., Kołaczek, P., Gałka, M., et al. (2016). A novel testate amoebae trait-based approach to infer environmental disturbance in Sphagnum peatlands. Sci. Rep. 6:33907. doi: 10. $1038 /$ srep33907 
Marcisz, K., Kołaczek, P., Gałka, M., Diaconu, A.-C., and Lamentowicz, M. (2020). Exceptional hydrological stability of a Sphagnum-dominated peatland over the late Holocene. Q. Sci. Rev. 231:106180. doi: 10.1016/j.quascirev.2020.106180

Marra, M. J., Schulmeister, J., and Smith, E. G. C. (2006). Reconstructing temperature during the Last Glacial Maximum from Lyndon Stream, South Island, New Zealand using beetle fossils and maximum likelihood envelopes. Q. Sci. Rev. 25, 1841-1849. doi: 10.1016/j.quascirev.2006.01.016

Marra, M. J., Smith, E. C. G., Schulmeister, J., and Leechen, R. (2004). Late Quaternary climate change in the Awatere Valley, South Island, New Zealand using a sine model with a maximum likelihood envelope on fossil beetle data. Q. Sci. Rev. 23, 1637-1650. doi: 10.1016/j.quascirev.2004.01.007

Matteodo, M., Wipf, S., Stöckli, V., Rixen, C., and Vittoz, P. (2013). Elevation gradient of successful plant traits for colonizing alpine summits under climate change. Environ. Res. Lett. 8:024043. doi: 10.1088/1748-9326/8/2/024043

Mauri, A., Davis, B. A. S., Collins, P. M., and Kaplan, J. O. (2015). The climate of Europe during the Holocene: a gridded pollen-based reconstruction and its multi-proxy evaluation. Q. Sci. Rev. 112, 109-127. doi: 10.1016/j.quascirev.2015. 01.013

McElwain, J. C., Mayle, F. E., and Beerling, D. J. (2002). Stomatal evidence for a decline in atmospheric $\mathrm{CO}_{2}$ concentration during the Younger Dryas stadial: a comparison with Antarctic ice core records. J. Q. Sci. 17, 21-29. doi: 10.1002/ jqs.664.abs

McElwain, J. C., Mitchell, F. J. G., and Jones, M. B. (1995). Relationship of stomatal density and index of Salix cinerea to atmospheric carbon-dioxide concentration in the Holocene. Holocene 5, 216-219. doi: 10.1177/095968369500500209

McGill, B. J., Enquist, B. J., Weiher, E., and Westoby, M. (2006). Rebuilding community ecology from functional traits. Trends Ecol. Evol. 21, 178-185. doi: 10.1016/j.tree.2006.02.002

Mortensen, M. F., Birks, H. H., Christensen, C., Holm, J., Noe-Nygaard, N., Odgaard, B. V., et al. (2011). Lateglacial vegetation development in Denmark - new evidence based on macrofossils and pollen from Slotseng, a small-scale site in southern Jutland. Q. Sci. Rev. 30, 2534-2550. doi: 10.1016/j.quascirev. 2011.04.018

Neumann, F., Schölzel, C., Litt, T., Hense, A., and Stein, M. (2006). Holocene vegetation history and climate history of the north Golan Heights (Near East). Veget. History Archaeobot. 16, 329-346. doi: 10.1007/s00334-006-0046-x

Odgaard, B. V. (1981). A Middle Weichselian moss assemblage from Hirtshals, Denmark, and some remarks on the environment 47,000 BP. Danmarks Geol. Unders. Årbog 1981, 5-45.

Osnas, J. L. D., Lichstein, J. W., Reich, P. B., and Pacala, S. W. (2013). Global leaf trait relationships: Mass, area, and the leaf economics spectrum. Science 340, 741-744. doi: 10.1126/science.1231574

Pearson, E. J., Juggins, S., Talbot, H. M., Weckström, J., Rosén, P., Ryves, D. B., et al. (2011). A lacustrine GDGT-temperature calibration from the Scandinavian arctic to antarctic: renewed potential for the application of GDGT-paleothermometry in lakes. Geochim. Cosmochim. Acta 75, 6225-6238. doi: 10.1016/j.gca.2011.07.042

Pearson, R. G., and Dawson, T. P. (2003). Predicting the impacts of climate change on the distribution of species: are bioclimatic envelope models useful? Glob. Ecol. Biogeogr. 12, 361-371. doi: 10.1046/j.1466-822X.2003.00042.x

Peppe, D. J., Baumgartner, A., Flynn, A., and Blonder, B. (2018). "Reconstructing paleoclimate and paleoecology using fossil leaves," in Methods in Paleoecology: Reconstructing Cenozoic Terrestrial Environments and Ecological Communities, eds D. A. Croft, D. F. Su, and S. W. Simpson (Cham: Springer), 289-317. doi: 10.1007/978-3-319-94265-0_13

Prentice, I. C., Guiot, J., Huntley, B., Jolly, D., and Cheddadi, R. (1996). Reconstructing biomes from palaeoecological data: a general method and its application to European pollen data at 0 and $6 \mathrm{ka}$. Climate Dynamics 12, 185-194. doi: 10.1007/BF00211617

Raunkiaer, C. (1907). Planterigels Livsformer og dered Betydning for Geografien. København: Gylendalske Boghandel-Nordisk Forlag.

Raunkiaer, C. (1934). The Life Forms of Plants and Statistical Plant Geography, being the collected papers of C. Raunkioer. Oxford: Clarenden Press.

Reitalu, T., Gerhold, P., Poska, A., Pärtel, M., Väli, V., and Veski, S. (2015). Novel insights into post-glacial vegetation change: functional and phylogenetic diversity in pollen records. J. Veg. Sci. 26, 911-922. doi: 10.1111/jvs.12300

Rivera, L., Baraza, E., Alcover, J. A., Bover, P., Rovira, C. M., and Bartolomé, J. (2014). Stomatal density and stomatal index of fossil Buxus from coprolites of extinct Myotragus balearicus Bate (Artiodactyla, Caprinae) as evidence of increased $\mathrm{CO}_{2}$ concentration during the late Holocene. Holocene 24, 876-880. doi: $10.1177 / 0959683614530445$

Rozema, J., Broekman, R. A., Blokker, P., Meijkamp, B. B., de Bakker, N., van de Staaij, J., et al. (2001). UV-B absorbance and UV-B absorbing compounds (paracoumaric acid) in pollen and sporopollenin: the perspective to track historic UV-B levels. J. Photochem. Photobiol. B Biol. 62, 108-117. doi: 10.1016/S10111344(01)00155-5

Rozema, J., van Geel, B., Björn, L. O., Lean, J., and Madronich, S. (2002). Toward solving the UV puzzle. Science 296, 1621-1622. doi: 10.1126/science.1070024

Rundgren, M., and Beerling, D. J. (1999). A Holocene $\mathrm{CO}_{2}$ record from the stomatal index of subfossil Salix herbacea L. leaves from northern Sweden. Holocene 9, 509-513. doi: 10.1191/095968399677717287

Rundgren, M., and Bennike, O. (2002). Century-scale changes of atmospheric $\mathrm{CO}_{2}$ during the last interglacial. Geology 30, 187-189.

Rundgren, M., and Björck, S. (2003). Late-glacial and early Holocene variations in atmospheric $\mathrm{CO}_{2}$ concentration indicated by high-resolution stomatal index data. Earth Planet. Sci. Lett. 213, 191-204. doi: 10.1016/S0012-821X(03)00 324-8

Rundgren, M., Björck, S., and Hammarlund, D. (2005). Last interglacial atmospheric $\mathrm{CO}_{2}$ changes from stomatal index data and their relation to climate variations. Glob. Planet. Change 49, 47-62. doi: 10.1016/j.gloplacha.2005.04.002

Rybnícek, K. (1973). “A comparison of the present and past mire environments of central Europe," in Quaternary Plant Ecology, eds H. J. B. Birks and R. G. West (Oxford: Blackwell), 237-261.

Salisbury, E. J. (1927). On the causes and ecological significance of stomatal frequency, with special reference to the woodland flora. Philos. Trans. R. Soc. Lond. B 216, 1-65. doi: 10.1098/rstb.1928.0001

Samuelsson, G. (1916). Über den Rückgang der Haselgrenze und anderer pflanzengeographischer Grenzlinien in Skandinavien. Bull. Geol. Instit. Uppsala 13, 93-114.

Sauer, P. E., Eglinton, T. I., Hayes, J. M., Schimmelmann, A., and Sessions, A. L. (2001). Compound-specific D/H ratios of lipid biomarkers from sediments as a proxy for environmental and climatic conditions. Geochim. Cosmochim. Acta 65, 213-222. doi: 10.1016/S0016-7037(00)00520-2

Schaffers, A. P., and Sýkora, K. V. (2000). Reliability of Ellenberg indicator values for moisture, nitrogen and soil reaction: a comparison with field measurements. J. Veget. Sci. 11, 225-244. doi: 10.2307/3236802

Schleuning, M., Neuschulz, E. L., Albrecht, J., Bender, I. M. A., Bowler, D. E., Dehling, D. M., et al. (2020). Trait-based assessments of climate-change impacts on interacting species. Trends Ecol. Evolut. 35, 319-328. doi: 10.1016/j.tree.2019. 12.010

Seddon, A. W. R., Jokerud, M., Barth, T., Birks, H. J. B., Krüger, L. C., Vandvik, V., et al. (2017). Improved quantification of UV-B absorbing compounds in Pinus sylvestris L. pollen grains using an internal standard methodology. Rev. Palaeobot. Palynol. 247, 97-104. doi: 10.1016/j.revpalbo.2017.08.007

Semenova, G., and Van Der Maarel, E. (2000). Plant functional types - a strategic perspective. J. Veg. Sci. 11, 917-922. doi: 10.2307/3236562

Shipley, B. (2010). From Plant Traits to Vegetation Structure. Cambridge: Cambridge University Press.

Shipley, B., De Bello, F., Cornelissen, J. H. C., Laliberté, E., Laughlin, D. C., and Reich, P. B. (2016). Reinforcing loose foundation stones in trait-based plant ecology. Oecologia 180, 923-931. doi: 10.1007/s00442-016-3549-x

Shuman, B. N., Newby, P., Huang, Y. S., and Webb, T. (2004). Evidence for the close climatic control of New England vegetation history. Ecology 85, 1297-1310. doi: 10.1890/02-0286

Steinthorsdottir, M., Wohlfarth, B., Kylander, M. E., Blaauw, M., and Reimer, P. J. (2013). Stomatal proxy record of $\mathrm{CO}_{2}$ concentrations from the last termination suggests an important role for $\mathrm{CO}_{2}$ at climate change transitions. Q. Sci. Rev. 68, 43-58. doi: 10.1016/j.quascirev.2013.02.003

Suding, K. N., and Goldstein, L. J. (2008). Testing the Holy Grail framework: using functional traits to predict ecosystem change. New Phytol. 180, 559-562. doi: 10.1111/j.1469-8137.2008.02650.x

Svenning, J.-C., Fløjgaard, C., Marske, K. A., Nógues-Bravo, D., and Normand, S. (2011). Applications of species distribution modeling to paleobiology. Q. Sci. Rev. 30, 2930-2947. doi: 10.1016/j.quascirev.2011.06.012

Svenning, J.-C., and Sandel, B. (2013). Disequilibrium vegetation dynamics under future climate change. Am. J. Bot. 100, 1266-1286. doi: 10.3732/ajb.1200469 
Ter Braak, C. J. F. (2017). Fourth-corner correlation is a score test statistic in a loglinear trait-environment model that is useful in permutation testing. Environ. Ecol. Statis. 24, 219-242. doi: 10.1007/s10651-017-0368-0

Ter Braak, C. J. F. (2019). New robust weighted averaging- and model-based methods for assessing trait-environment relationships. Methods Ecol. Evol. 10, 1962-1971. doi: 10.1111/2041-210x.13278

Ter Braak, C. J. F., and Barendregt, L. G. (1986). Weighted averaging of species indicator values: its efficiency in environmental calibration. Mathem. Biosci. 78, 57-72. doi: 10.1016/0025-5564(86)90031-3

Ter Braak, C. J. F., Cormont, A., and Dray, S. (2012). Improved testing of species traits-environment relationships in the fourth-corner problem. Ecology 93, 1525-1526. doi: 10.1890/12-0126.1

Ter Braak, C. J. F., and Gremmen, N. J. M. (1987). Ecological amplitudes of plant species and the internal consistency of Ellenberg's indicator values for moisture. Plant Ecol. 69, 79-87. doi: 10.1007/bf00038689

Ter Braak, C. J. F., Peres-Neto, P. R., and Dray, S. (2017). A critical issue in modelbased inference for studying trait-based community assembly and a solution. PeerJ 5:e2885. doi: 10.7717/peerj.2885

Ter Braak, C. J. F., Peres-Neto, P. R., and Dray, S. (2018). Simple parametric tests for trait-environment association. J. Veg. Sci. 29, 801-811. doi: 10.1111/jvs. 12666

Theophrastus. (1916). Enquiry into Plants (translated by A.F. Hort). Cambridge: Harvard University Press.

Thomas, E. K., McGrane, S., Briner, J. P., and Huang, Y. (2012). Leaf wax $\delta^{2} \mathrm{H}$ and varve-thickness climate proxies from proglacial lake sediments. Baffin Island, Arctic Canada. J. Paleolimnol. 48, 193-207. doi: 10.1007/s10933-012-9584-7

Thompson, K., Hodgson, J. G., Grime, J. P., Rorison, I. H., Band, S. R., and Spencer, R. E. (1993). Ellenberg numbers revisited. Phytocoenologia 23, 277-289. doi: $10.1127 /$ phyto/23/1993/277

Treurnicht, M., Pagel, J., Tonnabel, J., Esler, K. J., Slingsby, J. A., and Schurr, F. M. (2020). Functional traits explain the Hutchinsonian niches of plant species. Glob. Ecol. Biogeogr. 29, 534-545. doi: 10.1111/geb.13048

Uno, K. T., Polissar, P. J., Jackson, K. E., and deMenocal, P. B. (2016). Neogene biomarker record of vegetation change in eastern Africa. Proc. Natl. Acad. Sci. U.S.A. 113, 6355-6363. doi: 10.1073/pnas.1521267113

Ustin, S. L., and Gamon, J. A. (2010). Remote sensing of plant functional types. New Phytol. 186, 795-816. doi: 10.1111/j.1469-8137.2010.03284.x

Van Der Maarel, E. (1993). Relations between sociological-ecological species groups and Ellenberg indicator values. Phytocoenologia 23, 343-362. doi: 10. $1127 /$ phyto/23/1993/343

Van Der Sande, M. T., Gosling, W. D., Correa-Metrio, A., Prado-Junior, J., Poorter, L., Oliveira, R. S., et al. (2019). A 7000-year history of changing plant trait composition in an Amazonian landscape; the role of humans and climate. Ecol. Lett. 22, 925-935. doi: 10.1111/ele.13251

Van Der Water, P. K., Leavitt, S. W., and Betancourt, J. L. (1994). Trends in stomatal density and $\delta^{13} \mathrm{C} / \delta^{12} \mathrm{C}$ ratios of Pinus flexilis needles during the last glacial-interglacial cycle. Science 264, 239-243. doi: 10.1126/science.264.51 56.239

Van Hoof, T. B., Kürschner, W. M., Wagner, F., and Visscher, H. (2006). Stomatal index response of Quercus robur and Quercus petraea to the anthropogenic atmospheric $\mathrm{CO}_{2}$ increase. Plant Ecol. 183, 237-243. doi: 10.1007/s11258-0059021-3

Vaupell, C. (1863). De Danske Skove. Copenhagen: PG Philipsens Forlag.

Violle, C., Navas, M.-L., Vile, D., Kazakou, E., Fortunel, C., Hummel, I., et al. (2007). Let the concept of trait be functional! Oikos 116, 882-892. doi: 10.1111/ j.2007.0030-1299.15559.x

Violle, C., Reich, P. B., Pacala, S. W., Enquist, B. J., and Kattge, J. (2014). The emergence and promise of functional biogeography. Proc. Natl. Acad. Sci. U.S.A. 111, 13690-13696. doi: 10.1073/pnas.1415442111

Von Post, L. (1916). Mötet den 2 november 1916. Geolo. Förenin. Stockh. Förhand. 38, 383-394. doi: 10.1080/11035891609444403

Von Post, L. (1918). "Skogsträdpollen i sydsvenska torvmosselagerföljder," in Förhandlingar ved 16 Skandinavia Naturforskermøte 1916, 433-465.

Wagner, F., Aaby, B., and Visscher, H. (2002). Rapid atmospheric $\mathrm{CO}_{2}$ changes associated with the 8,200-years-B.P. cooling event. Proc. Natl. Acad. Sci. U.S.A. 99, 12011-12014. doi: 10.1073/pnas.182420699
Wagner, F., Bohncke, S. J. P., Dilcher, D. L., Kürschner, W. M., van Geel, B., and Visscher, H. (1999). Century-scale shifts in early Holocene atmospheric $\mathrm{CO}_{2}$ concentration. Science 284, 1971-1973. doi: 10.1126/science.284.5422. 1971

Wagner, F., Kouwenberg, L. L. R., van Hoof, T. B., and Visscher, H. (2004). Reproducibility of Holocene atmospheric $\mathrm{CO}_{2}$ records based on stomatal frequency. Q. Sci. Rev. 23, 1947-1954. doi: 10.1016/j.quascirev.2004. 04.003

Wagner-Cremer, F., Finsinger, W., and Moberg, A. (2010). Tracing growing degree-day changes in the cuticle morphology of Betula nana leaves: a new micro-phenological palaeo-proxy. J. Q. Sci. 25, 1008-1017. doi: 10.1002/jqs. 1388

Walther, G.-R., Berger, S., and Sykes, M. T. (2005). An ecological 'footprint' of climate change. Proc. R. Soc. B Biol. Sci. 272, 1427-1432. doi: 10.1098/rspb.2005. 3119

Wang, R., Chen, H. Y. H., Liu, X., Wang, Z., Wen, J., and Zhang, S. (2020). Plant phylogeny and growth form as drivers of the altitudinal variation in woody leaf vein traits. Front. Plant Sci. 10:1735. doi: 10.3389/fpls.2019. 01735

Wasylikowa, K. (1978). Plant remains from early and late medieval time found on the Wawel Hill in Cracow. Acta Palaeobot. 19, 115-198.

Wasylikowa, K. (1989). Paleoecological characteristics of the settlement periods of the Linear Pottery and Lengyel cultures at Cracow-nowa Huta (on the basis of plant material). Przeg. Archeolo. 36, 58-87.

Wasylikowa, K., Starkel, L., Niedziałkowska, E., Skiba, S., and Stworzewicz, E. (1985). Environmental changes in the Vistula Valley at Pleszów caused by Neolithic man. Przeg. Archeolo. 33, 19-55.

Weiher, E., van der Werf, A., Thompson, K., Roderick, M., Garnier, E., and Eriksson, O. (1999). Challenging Theophrastus: a common core list of plant traits for functional ecology. J. Veg. Sci. 10, 609-620. doi: 10.2307/323 7076

Westoby, M., Falster, D. S., Moles, A. T., Vesk, P. A., and Wright, I. J. (2002). Plant ecological strategies: some leading dimensions of variation between species. Ann. Rev. Ecol. Evol. Syst. 33, 125-159. doi: 10.1146/annurev.ecolsys.33.010802. 150452

Willis, K. J., Feurdean, A., Birks, H. J. B., Bjune, A. E., Breman, E., Broekman, R., et al. (2011). Quantification of UV-B flux through time using UV-B-absorbing compounds contained in fossil Pinus sporopollenin. New Phytol. 192, 553-560. doi: 10.1111/j.1469-8137.2011.03815.x

Woodward, F. I. (1986). Ecophysical studies on the shrub Vaccinium myrtillus L. taken from a wide altitudianl range. Oecologia 70, 580-586. doi: 10.1007/ bf00379908

Woodward, F. I. (1987). Stomatal numbers are sensitive to increases in $\mathrm{CO}_{2}$ from pre-industrial levels. Nature 327, 617-618. doi: 10.1038/327617a0

Woodward, I. (1988). The response of stomata to changes in atmospheric levels of $\mathrm{CO}_{2}$. Plants Today 1, 132-135.

Zanon, M., Davis, B. A. S., Marquer, L., Brewer, S., and Kaplan, J. O. (2018). European forest cover during the past 12,000 years: A palynological reconstruction based on modern analogs and remote sensing. Front. Plant Sci. 9:253. doi: 10.3389/fpls.2018.00253

Zechmeister, H. G., Kropik, M., Popovtschak, M., and Scharrer-Liška, G. (2019). Bryophytes in a latrine as indicators of climate change in the 17th century. Veg. History Archaeobot. 28, 575-581. doi: 10.1007/s00334-019-0 0717-6

Conflict of Interest: The author declares that the research was conducted in the absence of any commercial or financial relationships that could be construed as a potential conflict of interest.

Copyright (c) 2020 Birks. This is an open-access article distributed under the terms of the Creative Commons Attribution License (CC BY). The use, distribution or reproduction in other forums is permitted, provided the original author(s) and the copyright owner(s) are credited and that the original publication in this journal is cited, in accordance with accepted academic practice. No use, distribution or reproduction is permitted which does not comply with these terms. 